\title{
Quality characteristics and antioxidant activities of makgeolli prepared using rice nuruk containing bitter melon (Momordica charantia)
}

\author{
Kye Man Cho, Chung Eun Hwang, Hee Yul Lee, Min Ju Ahn, Ok Soo Joo* \\ Department of Food Science, Gyeongnam National University of Science and Technology, Jinju 52725, Korea
}

\section{여주 분말 함유 쌀누룩을 이용하여 제조된 막걸리의 품질 특성 및 항산화 활성}

\author{
조계만 · 황정은 · 안민주 · 이희율 · 주옥수* \\ 경남과학기술대학교 식품과학부
}

\begin{abstract}
Bitter melon powder (BMP) was used in the preparation of rice nuruk (RN) and makgeolli as one of raw materials. RN containing BMP (BMP-RN) was prepared by adding 0 2.0\% (w/w) BMP into rice. Fermentative microbial, and antioxidant characteristics of makgeolli were determined during the fermentation process. $\mathrm{pH}$ during fermentation decreased from $4.52(0 \%$ BMP-RN), $4.93(0.5 \%), 4.80(1.0 \%)$, and $4.88(2.0 \%)$ on the initial fermentation day (day 0 ) to $4.15,4.30,4.57$, and 4.59 , respectively, comesponding to increases in acidity from $0.64 \sim 0.70 \%$ to $1.17 \sim 1.28 \%$, respectively. Soluble solid contents increased from an initial $2.2 \sim 4.4 \mathrm{~g} / \mathrm{L}$ (day 0) to $9.0 \sim 9.3 \mathrm{~g} / \mathrm{L}$, and alcohol level increased up to $13.0 \%$ by the end of fermentation (day 7 ). Soluble phenolic contents increased from $0.92,1.01$, 1.32 , and $1.41 \mathrm{mg} / \mathrm{mL}$ on day 0 , to $1.85,2.03,2.24$, and $2.48 \mathrm{mg} / \mathrm{mL}$ on day 7 , respectively, while the levels of 2,2-diphenyl-1-picrylhydrazyl (DPPH) and 2,2' -azino-bis(3-ethylbenzthiazoline-6-sulfonic acid) diammonium salt (ABTS) radical scavenging activities and ferric reducing/antioxidant power (FRAP) assay increased from 46.95 70.04\%, 55.33 74.13\%, and $0.629 \sim 1.243$ on day 0 , respectively, to $54.98 \sim 83.4 \%$, 70.34 92.39\%, and 0.964 1.455 on day 7, respectively. Makgeolli made with BMP-RN had higher soluble phenolic contents and antioxidant activity than those of makgeolli made without BMP-RN. These results suggested that BNP-RN made a functional makgeolli.
\end{abstract}

Key words : bitter melon, rice nuruk, makgeolli, soluble phenolics, antioxidant

\section{서 론}

한국의 대표적인 전통 발효주인 막걸리는 천여년 이상 양조되어 왔으며 일명 탁주라고 하고 당화와 발효 공정을 통하여 생산되며 알코올 함량이 낮은 저도주의 일종이다 $(1,2)$. 막걸리는 탄수화물과 단백질 등의 영양원이 풍부하

*Corresponding author. E-mail : osjoo@gntech.ac.kr Phone : 82-55-751-3273, Fax : 82-55-751-3279

Received 1 December 2015; Revised 3 March 2016; Accepted 4 March 2016.

Copyright (c) The Korean Society of Food Preservation. All rights reserved.
게 함유되어 있으며, 발효과정 중 비타민뿐만 아니라 필수 아미노산, aromatic flavors 및 유기산 등이 함유되어 있다 (2-4). 특히 Wang 등(5)은 막걸리로부터 항산화 물질인 4 -hydroxybenzaldehyde,2-(4-hydroxylphenyl) ethanol(tyrosol), trans-ferulic acid, cis-ferulic acid 및 $1 \mathrm{H}$-indole-3-ethanol(tryptophol) 등을 분리하여 보고하였다 누룩은 거칠게 분쇄한 곡물에 물을 가하고 성형하여 자 연의 미생물을 번식시킨 것으로, 막걸리 발효 과정에서 전 분질을 분해해서 포도당으로 만들어 주는 주요 효소원이 되며 $(6,7)$, 누룩에 따라 미생물상의 차이가 나며, 이 때문에 막걸리 발효과정에 효소활성, 유기산 생성력 및 알코올 발 효능 등이 달라지므로 막걸리의 휘발성 풍미 성분, 맛 및 
색상 등의 품질특성에 큰 영향을 미치는 것으로 보고되어 있다(1,7-9). 그러나 누룩의 이런 특성으로 인하여 일정한 품질을 지닌 막걸리 생산관리에 어려운 점이 있어, 대부분 일본에서 도입된 입국(koji) 방식으로 막걸리를 제조하고 있다. 한편 몇몇 연구들에서 기능성 소재를 첨가하여 누룩 을 제조하고 이를 이용한 기능성 막걸리 제조에 관한 연구 가 보고되어 있다 $(1,10)$.

여주(Momordica charantia)는 박과의 덩이식물로 bitter squash, bitter gourd, bitter melon, karela 및 goya로도 불리며 일반적으로 아시아, 동아프리카, 중앙아메리카 및 남아메 리카와 같은 열대지방에서 재배되며 당뇨의 민간요법 치료 제로써 널리 사용되고 있다 $(11,12)$. 여주는 glycosides, triterpenes, polyphenols, saponins, alkaloids, proteins, $\mathrm{K}, \mathrm{Ca}$, $\mathrm{Mg}, \mathrm{Fe}, \mathrm{Zn}$ 등의 미네랄과 vitamin $\mathrm{C}, \beta$-carotene을 다량 함유하고 있으며, 특히 미성숙과는 비타민C, 비타민A와 철의 주요 공급원이 되고 있다(11-14).

따라서 본 연구에서는 국내에서 생산되는 여주의 활용성 증대를 위해 여주 첨가 쌀누룩을 제조하고 이를 이용하여 막걸리 제조하여 막걸의 발효 중 이화학적 특성과 항산화 활성을 검토하였다.

\section{재료 및 방법}

\section{원료, 균주 및 시약}

멥쌀은 함양군 소재 함양영농조합법인 미곡처리장에서 2014년 수확하여 도정한 것을 공급받아 사용하였고, 여주 는 2014년 함양군 안의면 일대에 재배되어 수확된 것을 함양영농조합법인 천령식품점에서 건조 여주 분말(BMP, bitter melon powder)을 공급받아 사용하였다. 누룩 제조를 위한 곰팡이는 경상대학교 식품공학과 식품미생물실험실 에서 보관 중인 Aspergillus oryzae를 분양 받아 사용하였고, 막걸리 발효를 위한 효모는 한국종균협회(KCCM, Korean Culture Center Microorganisms)에서 분양받아 보관하고 있 던 Saccharomyces cerevisiae KCCM 12684을 사용하였다. 미생물 배양용 배지는 Lactobacilli MRS broth/agar 및 potato dextrose agar는 Difco사(Becton Dickinson Co., Sparks, MD, USA)에서 구입하여 사용하였다. 2 N Folin-Cicalteu phenol, 2,2-diphenyl-1-picrylhydrazyl(DPPH), 2,2 ' -azino-bis(3ethylbenzthiazoline-6-sulphonic acid) diammonium salt(ABTS), 2,4,6-tri(2-pyridyl-1,3,5-triazine)(TPTZ) 및 gallic acid은 Sigma-Aldrich사(Saint Louis, MO, USA)에서 구입하여 사 용하였다. 그 외 기타 시약은 필요에 따라 특급 혹은 1 급을 구입하여 사용하였다.

\section{여주 분말 함유 쌀누룩 제조}

여주 함유 쌀누룩 제조는 Cho 등(1)의 방법에 준하여
제조하였다. $A$ oryzae의 한 plate를 멸균증류수 $100 \mathrm{~mL}$ 에 포자를 현탁시켜 누룩 제조를 위한 종균으로 사용하였다. 멥쌀 $5 \mathrm{~kg}$ 을 달아 물로 세척한 다음 약 3 4배의 물을 가하고 $20^{\circ} \mathrm{C} \pm 2$ 에서 12 시간 수침 후 30 분간 물기를 제거하였다. 물기가 제거된 쌀 무게에 건조 여주 분말을 $0,0.5,1.0$ 및 $2.0 \%(\mathrm{w} / \mathrm{w})$ 첨가하고 미리 준비한 $A$ oryzae 종균 100 $\mathrm{mL}(5 \%, \mathrm{v} / \mathrm{w})$ 과 멸균증류수 $200 \mathrm{~mL}$ 을 가하여 반죽하였다. 누룩틀에 $500 \mathrm{~g}$ 누룩 반죽을 채우고 다진 후 성형된 누룩을 트레이에 넣고 한지로 덮은 후 $20^{\circ} \mathrm{C}$ 에서 5 일간 균사가 완전 히 성장할 때 까지 발효시켰다. 발효가 끝난 누룩은 실온에 서 자연건조 시킨 후 균사를 제거하고 분쇄하여 분말을 제조하였다. 분쇄된 누룩은 $4^{\circ} \mathrm{C} \pm 3$ 냉장실에서 보관하면서 실험에 사용하였다.

\section{막걸리 제조}

막걸리 제조 역시 Cho 등(1)의 방법에 준하여 제조하였 다. 쌀 $2,000 \mathrm{~g}$ 을 물로 세척한 다음 충분한 물을 부은 후 실온에서 12 시간 침지하였고 30 분간 물기를 제거하였다. 물기가 제거된 각각의 시료를 $100^{\circ} \mathrm{C}$ 에서 1 시간 동안 증자 후 냉각하였다. 막걸리 제조는 누룩 $(200 \mathrm{~g})$ 과 용수 $(400 \mathrm{~mL})$ 를 $10 \mathrm{~L}$ 발효조에 넣고 효모 $40 \mathrm{~mL}$ 을 접종하고 $25^{\circ} \mathrm{C}$ 에서 1 일 동안 발효하여 밑술제조(1단 담금)하고 증자한 곡류 $2,000 \mathrm{~g}$, 누룩 $200 \mathrm{~g}$ 및 정제수 $4,100 \mathrm{~mL}$ 을 1 단 담금한 발효조에 넣고 2 단 담금하여 $25^{\circ} \mathrm{C}$ 에서 7 일 동안 발효하였 다. 7 일 발효된 막걸리는 4겹의 치즈크로스로 여과하여 이 후 실험에 사용하였다.

\section{$\mathrm{pH}$ 와 산도}

막걸리 발효 중 $\mathrm{pH}$ 는 여과한 시료 $50 \mathrm{~mL}$ 를 사용하여 측정하였다(pH meter model 3510, Jenway, London, UK). 총산은 여과한 시료 $10 \mathrm{~mL}$ 에 $0.1 \mathrm{~N} \mathrm{NaOH}$ 용액으로 $\mathrm{pH}$ $8.3 \pm 0.1$ 까지 중화시키데 소요된 $\mathrm{mL}$ 수를 구한 후 초산 (acetic acid)으로 환산하였다(15).

$$
\text { 총산 }(\%)=\text { 산도 } \times 0.006 \times 10
$$

\section{가용성 고형분(Brix)와 알코올 함량}

막걸리 발효 중 가용성 고형분 $\left({ }^{\circ} \mathrm{Brix}\right)$ 는 여과한 시료를 원심분리기(Hanil micro-12, Daejeon, Korea)로 원심분리한 후 상등액을 취하여 굴절당도계(N-1a, Atago Co., Tokyo, Japan)를 이용하여 측정하였다. 알코올 함량은 여과한 시료 $100 \mathrm{~mL}$ 에 동량의 증류수를 가한 후 증류한 다음 주정계를 이용하여 측정하였으며 Gay Luccac Table을 이용하여 $15^{\circ} \mathrm{C}$ 로 보정하였다(7).

\section{생균수}

막걸리 발효 중 생균수 측정은 여과한 시료를 멸균생리 
식염수로 10 단 희석법으로 적당히 희석하고 bromocresol purple(BCP) $0.02 \%$ 를 함유한 Lactobacilli MRS 평판배지에 도말하고 $30^{\circ} \mathrm{C}$ 에서 48 시간 배양 후 황색 집락을 계수하여 유산균수로 하였고, 효모균수는 Potato Dextrose Agar에 chlorampheaicol $(1.5 \mathrm{mg} / \mathrm{mL})$ 이 함유된 배지에 도말한 후 $30^{\circ} \mathrm{C}$ 에서 48 시간 배양 후 생성된 집락을 계수하여 시료 $\mathrm{mL}$ 당 colony forming unit $(\mathrm{CFU} / \mathrm{mL})$ 로 표시하였다(7).

\section{수용성 phenolics 함량}

막걸리 발효 중 수용성 phenolics는 Folin-Ciocalteu법(16) 으로 측정하였다. 발효액을 원심분리한 후 상등액을 취하 여 $0.45 \mu \mathrm{m}$ membrane filter(Dismic-25CS, Toyoroshikaisha Ltd., Tokyo, Japan)로 여과하여 여과액을 20 배 희석한 후 $0.5 \mathrm{~mL}$ 를 시험관에 분주하고 $25 \% \mathrm{Na}_{2} \mathrm{CO}_{3}$ 용액 $0.5 \mathrm{~mL}$ 를 첨가하여 3 분간 정치시킨 후 여기에 2N-Folin-Ciocalteu phenol 시약 $0.25 \mathrm{~mL}$ 를 첨가하여 혼합하고 $30^{\circ} \mathrm{C} \pm 1$ 의 배양 기에서 1 시간 동안 정치시켜 발색시켰다. 반응액은 분광광 도계(Spectronic 2D, Thermo Electron Co., Waltham, MA, USA)를 이용하여 $750 \mathrm{~nm}$ 에서 흡광도를 측정하였다. 이때 수용성 phenolics 함량은 gallic acid를 이용하여 작성한 표준 곡선으로부터 함량을 구하였다.

\section{$\mathrm{DPPH}$ 라디칼 소거 활성}

$\mathrm{DPPH}$ 라디칼 소거활성은 $1.5 \times 10^{-4} \mathrm{M} \mathrm{DPPH}$ 용액 0.8 $\mathrm{mL}$ 과 5 배 희석한 발효 여과액 $0.2 \mathrm{~mL}$ 을 가한 후 10 초간 vortex하고 실온에서 30 분 방치한 후 분광광도계(Spectronic 2D, Thermo Electron Co., Waltham, MA, USA)를 이용하여 $525 \mathrm{~nm}$ 에서 흡광도를 측정하였다(15). 음성 대조구는 증류 수를 사용하였고, 활성은 실험구와 음성 대조구의 흡광도 를 구하여 아래와 같이 백분율(\%)로 표시하였다.

$\mathrm{DPPH}$ 라디칼 소거 활성(\%)

= [1-(실험구의 흡광도/음성 대조구의 흡광도) $] \times 100$

\section{ABTS 라디칼 소거 활성}

$7 \mathrm{mM} \mathrm{ABTS}$ 용액과 $280 \mathrm{mM} \mathrm{K} \mathrm{K}_{2} \mathrm{O}$ 용액을 동량으로 섞어 암실에서 14 16시간 방치시켜 라디칼을 생성시킨 후 이를 무수 에탄올과 약 $1: 88$ 비율로 섞어 $734 \mathrm{~nm}$ 에서 대조 구의 흡광도 값이 $0.70 \pm 0.02$ 가 되도록 에탄올로 조절하여 사용하였다. 10배 희석한 발효 여과액 $0.1 \mathrm{~mL}$ 와 ABTS 용액 $0.9 \mathrm{~mL}$ 를 혼합하여 30 초간 진탕 혼합하고 3 분간 반응시킨 후 $734 \mathrm{~nm}$ 에서 흡광도를 측정하였다(15). ABTS 라디칼 소거활성 역시 실험구와 음성 대조구의 흡광도를 구하여 아래와 같이 백분율(\%)로 표시하였다.

$\mathrm{ABTS}$ 라디칼 소거 활성(\%)

= $[1-($ 실험구의 흡광도/음성 대조구의 흡광도 $)] \times 100$
FRAP(Ferric Reducing/antioxidant Power) 환원력

환원력 분석을 위한 $\mathrm{FRAP}$ 시약은 $300 \mathrm{mM}$ sodium acetate buffer(pH 3.6), TPTZ 시약 $(10 \mathrm{mM}$ in $40 \mathrm{mM} \mathrm{HCl})$ 및 20 $\mathrm{mM} \mathrm{FeCl}_{3}$ 용액을 10:1:1의 부피 비율로 혼합하여 제조하였 고 $37^{\circ} \mathrm{C}$ 에서 15 분간 예열하여 사용하였다. 5 배 희석한 발효 여과액 시료 $0.05 \mathrm{~mL}$ 와 FRAP 시약 $0.95 \mathrm{~mL}$ 를 시험관에 분주하고 진탕 혼합한 후 15 분간 반응시키고 분광광도계를 사용하여 $593 \mathrm{~nm}$ 에서 흡광도를 측정하였다(15).

\section{통계처리}

각 실험은 3 회 반복 수행하였고, 실험 결관는 SSP 12.0 package를 사용하여 분산 분석을 수행하여 평균표표준편차 로 표기하였으며, 유의성 검정은 $\mathrm{p}<0.05$ 수준에서 Dumcan's multiple range test를 실시하였다.

\section{결과 및 고찰}

\section{발효 중 이화학적 특성 변화}

여주 분말 첨가 쌀누룩(BMP-RN, bitter melon powder-rice $n u r u k$ 을 이용하여 제조한 막걸리 발효 중 이화학적 특성을 살펴본 결과는 Table 1 과 같았다.

여주 분말 무첨가 쌀누룩(대조구, $0 \% \mathrm{BMP}-\mathrm{RN}$ )으로 제 조한 막걸리의 담금 직후 $\mathrm{pH}$ 는 4.52 에서 발효 1 일째 3.57 으 로 급격히 낮아졌고, 이 후에 서서히 증가하여 발효 7일째 4.15 있었다. 한편 여주 분말 첨가 쌀누룩은 무첨가구보다 높은 $\mathrm{pH}$ 를 나타내었고, $\mathrm{pH}$ 는 담금 직후 $4.83(1.0 \%$ BMP-RN)-4.59(0.5\% BMP-RN)에서 역시 무첨가구와 동일 하게 발효 1 일째 급격히 증가였고, 이후 서서히 증가하였다 (Table 1). $\mathrm{pH}$ 는 막걸리 발효 진행 정도와 알코올 생성 정도 를 짐작할 수 있는 중요한 지표의 하나로 이용된다(17). 담금 직후 $\mathrm{pH}$ 차이는 누룩의 차이에 기인한 것으로 판단되 었으며, 여주 첨가 누룩으로 제조한 막걸 리가 여주 무첨가 누룩보다 $\mathrm{pH}$ 가 높았으나, 발효 1 일째 거의 산성 부근인 4.0 으로 초기 잡균 오염 등에 대해서는 안전할 것으로 판단 되었다. Choi 등(18)은 시판누룩 이용 석탄주 발효 중 발효 초기 $\mathrm{pH}$ 는 급격히 감소한 후 발효 중기부터 완만히 증가한 다고 보고하여 본 연구 결과와 일치하였다. 또한 Cho 등(1) 은 자색고구마 분말 첨가 누룩으로 제조한 막걸리의 경우 무첨가구보다 담금 직후 $\mathrm{pH}$ 가 낮다고 보고하여 본 연구와 는 상반된 결과를 보였으며, 발효 중에는 발효 1 일째까지 급격히 $\mathrm{pH}$ 가 감소하고 이 후 발효 종료 시점까지 서서히 증가한다고 하여 발효 양상은 유사하였다.

산도는 발효가 진행됨에 따라 꾸준히 증가하는 경향을 보여 발효 초기 $0.60 ~ 0.78 \%$ 에서 발효 종기 1.18 1.42\% 있 었다(Table 1). 산도는 막걸리의 성분 변화를 쉽게 알 수 있는 요인일 뿐만 아니라 발효 과정에서 복합적으로 생성되 
Table 1 . Change in $\mathrm{pH}$, acidity, ${ }^{\circ} \mathrm{Brix}$, and alcohol contents of makgeulli during fermentation using different bitter melon powder-rice nuruk (BMP-RN)

\begin{tabular}{|c|c|c|c|c|c|}
\hline \multirow{2}{*}{$\begin{array}{l}\text { Fermentation } \\
\text { time (day) }\end{array}$} & \multirow{2}{*}{$\begin{array}{l}\text { BMP- } \\
\text { RN }\end{array}$} & \multicolumn{4}{|c|}{ Parameters $^{2)}$} \\
\hline & & $\mathrm{pH}$ & $\begin{array}{c}\text { Acidity } \\
(\%, \text { as acetic acid) }\end{array}$ & ${ }^{\circ}$ Brix & $\begin{array}{l}\text { Alcohol } \\
(\%, \mathrm{v} / \mathrm{v})\end{array}$ \\
\hline \multirow{4}{*}{0} & $0 \%$ & $4.52 \pm 0.13^{\mathrm{ab} 2)}$ & $0.74 \pm 0.03^{c}$ & $2.2 \pm 0.09^{f}$ & $\mathrm{ND}^{3)}$ \\
\hline & $0.5 \%$ & $4.93 \pm 0.15^{\mathrm{a}}$ & $0.78 \pm 0.00^{c}$ & $2.6 \pm 0.11^{\mathrm{f}}$ & ND \\
\hline & $1.0 \%$ & $4.80 \pm 0.12^{\mathrm{a}}$ & $0.60 \pm 0.02^{\mathrm{c}}$ & $3.0 \pm 0.12^{\mathrm{f}}$ & ND \\
\hline & $2.0 \%$ & $4.88 \pm 0.13^{\mathrm{a}}$ & $0.78 \pm 0.03^{c}$ & $4.4 \pm 0.10 \mathrm{e}$ & $\mathrm{ND}$ \\
\hline \multirow{4}{*}{1} & $0 \%$ & $3.57 \pm 0.08^{\mathrm{d}}$ & $0.92 \pm 0.05^{b c}$ & $5.6 \pm 0.30^{d}$ & $7.0 \pm 0.30^{c}$ \\
\hline & $0.5 \%$ & $3.90 \pm 0.10^{c}$ & $1.04 \pm 0.04^{\mathrm{bc}}$ & $5.6 \pm 0.26^{d}$ & $6.0 \pm 0.28^{c}$ \\
\hline & $1.0 \%$ & $3.93 \pm 0.12^{c}$ & $1.12 \pm 0.03^{\mathrm{b}}$ & $6.4 \pm 0.28^{\mathrm{cd}}$ & $6.0 \pm 0.32^{\mathrm{c}}$ \\
\hline & $2.0 \%$ & $4.26 \pm 0.13^{b}$ & $1.22 \pm 0.07^{\mathrm{b}}$ & $6.8 \pm 0.32^{\mathrm{cd}}$ & $8.0 \pm 0.40^{\mathrm{b}}$ \\
\hline \multirow{4}{*}{2} & $0 \%$ & $3.78 \pm 0.11^{\mathrm{cd}}$ & $1.60 \pm 0.01^{\mathrm{a}}$ & $6.4 \pm 0.29^{\text {cd }}$ & $9.0 \pm 0.44^{b}$ \\
\hline & $0.5 \%$ & $3.97 \pm 0.12^{\mathrm{c}}$ & $1.40 \pm 0.03^{\mathrm{a}}$ & $6.4 \pm 0.25^{\mathrm{cd}}$ & $9.0 \pm 0.45^{b}$ \\
\hline & $1.0 \%$ & $4.13 \pm 0.10^{b c}$ & $1.32 \pm 0.05^{\mathrm{ab}}$ & $6.6 \pm 0.33^{\text {cd }}$ & $11.0 \pm 0.52^{\mathrm{ab}}$ \\
\hline & $2.0 \%$ & $4.39 \pm 0.09^{b}$ & $1.60 \pm 0.04^{\mathrm{a}}$ & $8.0 \pm 0.42^{b}$ & $11.0 \pm 0.55^{\mathrm{ab}}$ \\
\hline \multirow{4}{*}{3} & $0 \%$ & $3.88 \pm 0.12^{\mathrm{c}}$ & $1.46 \pm 0.02^{\mathrm{a}}$ & $7.0 \pm 0.33^{c}$ & $11.0 \pm 0.53^{\mathrm{ab}}$ \\
\hline & $0.5 \%$ & $3.99 \pm 0.11^{c}$ & $1.44 \pm 0.06^{\mathrm{a}}$ & $7.0 \pm 0.27^{\mathrm{c}}$ & $11.0 \pm 0.57^{7 \mathrm{~b}}$ \\
\hline & $1.0 \%$ & $4.21 \pm 0.13^{\mathrm{b}}$ & $1.32 \pm 0.03^{\mathrm{ab}}$ & $8.0 \pm 0.35^{b}$ & $13.0 \pm 0.61^{\mathrm{a}}$ \\
\hline & $2.0 \%$ & $4.43 \pm 0.13^{\mathrm{ab}}$ & $1.24 \pm 0.02^{\mathrm{b}}$ & $8.4 \pm 0.40^{\mathrm{ab}}$ & $13.0 \pm 0.66^{\mathrm{a}}$ \\
\hline \multirow{4}{*}{4} & $0 \%$ & $3.96 \pm 0.08^{c}$ & $1.22 \pm 0.02^{b}$ & $7.4 \pm 0.29^{c}$ & $12.0 \pm 0.60^{\mathrm{a}}$ \\
\hline & $0.5 \%$ & $4.03 \pm 0.10^{c}$ & $1.12 \pm 0.05^{\mathrm{b}}$ & $7.4 \pm 0.25^{\mathrm{c}}$ & $12.0 \pm 0.57^{\mathrm{a}}$ \\
\hline & $1.0 \%$ & $4.30 \pm 0.09^{\mathrm{ath}}$ & $1.10 \pm 0.05^{b}$ & $8.4 \pm 0.38^{b}$ & $13.0 \pm 0.68^{\mathrm{a}}$ \\
\hline & $2.0 \%$ & $4.50 \pm 0.06^{\mathrm{ab}}$ & $1.08 \pm 0.02^{b}$ & $8.8 \pm 0.40^{\mathrm{ab}}$ & $13.0 \pm 0.65^{\mathrm{a}}$ \\
\hline \multirow{4}{*}{5} & $0 \%$ & $4.07 \pm 0.11^{b}$ & $1.30 \pm 0.03^{\mathrm{ab}}$ & $7.4 \pm 0.32^{c}$ & $12.0 \pm 0.64^{\mathrm{a}}$ \\
\hline & $0.5 \%$ & $4.14 \pm 0.12^{\mathrm{b}}$ & $1.20 \pm 0.03^{\mathrm{b}}$ & $7.4 \pm 0.27^{\mathrm{c}}$ & $12.0 \pm 0.65^{\mathrm{a}}$ \\
\hline & $1.0 \%$ & $4.38 \pm 0.10^{\mathrm{ab}}$ & $1.08 \pm 0.04^{b}$ & $8.4 \pm 0.35^{b}$ & $13.0 \pm 0.70^{\mathrm{a}}$ \\
\hline & $2.0 \%$ & $4.57 \pm 0.15^{\mathrm{ab}}$ & $1.14 \pm 0.01^{b}$ & $8.8 \pm 0.39^{\mathrm{ab}}$ & $13.0 \pm 0.68^{\mathrm{a}}$ \\
\hline \multirow{4}{*}{6} & $0 \%$ & $4.17 \pm 0.10^{\mathrm{bc}}$ & $1.30 \pm 0.06^{\mathrm{ab}}$ & $8.4 \pm 0.40^{b}$ & $13.0 \pm 0.64^{\mathrm{a}}$ \\
\hline & $0.5 \%$ & $4.23 \pm 0.08^{\mathrm{b}}$ & $1.22 \pm 0.07^{\mathrm{b}}$ & $8.4 \pm 0.42^{b}$ & $13.0 \pm 0.67^{\mathrm{a}}$ \\
\hline & $1.0 \%$ & $4.47 \pm 0.16^{\mathrm{ab}}$ & $1.10 \pm 0.04^{b}$ & $9.0 \pm 0.38^{\mathrm{a}}$ & $13.0 \pm 0.66^{\mathrm{a}}$ \\
\hline & $2.0 \%$ & $4.68 \pm 0.14^{\mathrm{ab}}$ & $1.22 \pm 0.02^{\mathrm{b}}$ & $9.2 \pm 0.44^{\mathrm{a}}$ & $13.0 \pm 0.65^{\mathrm{a}}$ \\
\hline \multirow{4}{*}{7} & $0 \%$ & $4.15 \pm 0.12^{\mathrm{bc}}$ & $1.42 \pm 0.03^{\mathrm{a}}$ & $9.3 \pm 0.40^{\mathrm{a}}$ & $13.0 \pm 0.69^{\mathrm{a}}$ \\
\hline & $0.5 \%$ & $4.30 \pm 0.10^{b}$ & $1.40 \pm 0.02^{\mathrm{a}}$ & $8.6 \pm 0.38^{\mathrm{ab}}$ & $13.0 \pm 0.68^{\mathrm{a}}$ \\
\hline & $1.0 \%$ & $4.57 \pm 0.11^{\mathrm{ab}}$ & $1.18 \pm 0.05^{b}$ & $9.2 \pm 0.43^{\mathrm{a}}$ & $13.0 \pm 0.64^{\mathrm{a}}$ \\
\hline & $2.0 \%$ & $4.75 \pm 0.13^{\mathrm{a}}$ & $1.30 \pm 0.04^{\mathrm{ab}}$ & $9.2 \pm 0.39^{\mathrm{a}}$ & $13.0 \pm 0.65^{\mathrm{a}}$ \\
\hline
\end{tabular}

${ }^{1)}$ Sacch. cerevisiae KCCM 12684 seeds were innoculated by $5.0 \%$ (v/v) into makgeolli and fermented at $25^{\circ} \mathrm{C}$ for 7 days.

${ }^{2}$ All values are means $\mathrm{SD}$ of determinations in three independent experiments. Means with different lowercase letters $(a, b, c, d$, e, and f) indicate significant $(\mathrm{p}<0.05)$ differences of fermentation times by Tukey's multiple range test.

${ }^{3} \mathrm{ND}$, not detected

므로 $\mathrm{pH}$ 와 함께 막걸리의 발효 진행 상황을 알 수 있는 중요한 지표성분이 되며, 휘발성 향기 성분과 함께 막걸리 의 감미, 신미, 고미 및 삽미 등과 더불어 막걸리의 조화미나 보존성에 영향을 준다 $(6,19)$. 이는 발효가 진행되면서 효모 나 젖산균 등의 미생물 작용으로 생성된 각종 유기산에
의해 산도가 증가된 것으로 판단되었다. 이러한 Cho 등(1) 은 $\mathrm{pH}$ 와 산도의 차이는 자색고구마 분말 첨가에 따라 제조 된 누룩의 차이에 기인한 것으로 추정하였고, 본 연구 역시 $\mathrm{pH}$ 와 산도의 차이는 여주 분말 첨가에 따라 제조된 누룩의 차이에 기인한 것으로 판단되었다.

가용성 고형분(brix)은 여주 분말 첨가량이 증가할수록 가용성 고형분은 증가하여, 담금 직후 무첨가구는 $2.2{ }^{\circ} \mathrm{Brix}$ 였고, 여주 분말 첨가구는 $2.6 \sim 4.4{ }^{\circ} \mathrm{Brix}$ 수준이었다. 한편 발효 1 일째까지 가용성고형분은 급격히 증가하여 5.6 ${ }^{\circ} \mathrm{Brix}(0 \%$ 및 $0.5 \% \mathrm{BMP}-\mathrm{RN}), 6.4{ }^{\circ} \mathrm{Brix}(1.0 \% \mathrm{BMP}-\mathrm{RN})$ 및 $6 .{ }^{\circ} \mathrm{Brix}(2.0 \% \mathrm{BMP}-\mathrm{RN})$ 수준이었으며, 이후에 서서히 증 가하여 발효 종료 시점에는 $8.6{ }^{\circ} \mathrm{Brix}(0.5 \% \mathrm{BMP}-\mathrm{RN})-9.3$ ${ }^{\circ} \mathrm{Brix}(0 \% \mathrm{BMP}-\mathrm{RN})$ 수준 이었으나, 자색고구마 분말 첨가 별 당도는 거의 없었다(Table 1). 발효주 내의 가용성 고형분 특히 당 함량은 효모의 알코올 생성을 결정짓고 주류의 향기성분과 단맛에 영향을 주는 것으로 알려져 있다 $(17,18) . \operatorname{Kim}$ 등(20)의 설기떡을 이용한 흑마늘 막걸리 발효 중 당도는 발효 1 일째까지 급속히 증가한 후 발효 종기까지 서서히 증가한다고 본 연구결과 유사하였고, 역시. 자색고 구마 분말 첨가 누룩 이용 막걸리 발효 중 연구결과도 본 연구결과와 동일한 발효 양상을 나타내었다.

Table 1에서 보는 바와 같이 알코올 생성량은 산도 및 가용성 고형분의 변화와 동일하게 발효 1 일까지 급격히 증가하여 6.0\%(0.5 및 1.0\% BMP-RN), 7.0\%(0\% BMP-RN) 및 $8.0 \%(1.0 \% \mathrm{BMP}-\mathrm{RN})$ 로 유의적으로 증가하였고, 이 후 발효가 진행에 따라 증가의 양상은 약간 차이가 있었으나, 발효 7일째 모든 시료에서 $13.0 \%$ 생성되었다. 알코올 함량 은 술의 보존성이나 향미에 영향을 주는 중요한 성분으로 술덧 중 다소 높아야 한다고 보고되고 있다(7,21). 본 연구의 여주 분말 쌀누룩으로 제조한 막걸리 발효 중 알코올 함량 의 차이는 누룩의 당화력 차이인 것으로 판단되었으나, 발 효 종료 시점에서는 차이가 없었고, 자색고구마 분말 첨가 쌀누룩으로 제조한 막걸리 역시 본 연구와 유사하였다(1). 향후 발효 과정 중 당 함량 및 당화력, 알코올 생성량, 효모 활성과의 상관관계를 구명하는 연구가 필요할 것으로 사료 된다.

\section{발효 중 미생물 변화}

BMP-RN로 제조한 막걸리의 발효 중 젖산균수와 효모균 수를 측정한 결과는 Table 2 와 같았다. 발효 기간 동안 젖산 균은 발효 6일째까지 증가하다가 발효 7일째 약간 감소하 였고, 효모균수는 발효 4일째까지 증가하였고 이 후 감소하 는 경향을 나타내었다. 젖산균수는 담금 직후 6.37 6.67 $\log \mathrm{CFU} / \mathrm{mL}$ 수준에서 발효 완료 후 8.11 8.36 $\log \mathrm{CFU} / \mathrm{mL}$ 수준으로 유의적으로 증가하였으며, 효모균수는 6.15 6.77 $\log \mathrm{CFU} / \mathrm{mL}$ 에서 8.00 8.19 $\log \mathrm{CFU} / \mathrm{mL}$ 수준으로 역시 유 의적으로 증가하였다. 한편 발효가 진행 동안 실험군간에 
유산균수와 효모균수는 유의적 차이가 없었다.

막걸리 발효 중 유기산이 생성되어 $\mathrm{pH}$ 가 감소하고 알코 올, 아미노산 및 유기산 등의 화합물이 상호 반응하여 에스 테르 등의 향미성분이 생성되는데, 이 때 알코올, 유기산, 아미노산 등의 생성에 중요한 역할을 하는 것이 미생물이다

Table 2. Change in viable cell numbers of lactic acid bacteria (LAB) and yeast of makgeulli during fermentation using different bitter melon powder-rice nuruk (BMP-RN) ${ }^{1)}$

\begin{tabular}{|c|c|c|c|}
\hline \multirow{2}{*}{$\begin{array}{l}\text { Fermentation } \\
\text { time (day) }\end{array}$} & \multirow{2}{*}{ BMP--RN } & \multicolumn{2}{|c|}{ Viable cell numbers $(\log \mathrm{CFU} / \mathrm{mL})^{2)}$} \\
\hline & & Lactic acid bacteria & Yeast \\
\hline \multirow{4}{*}{0} & $0 \%$ & $6.67 \pm 0.35^{22)}$ & $6.77 \pm 0.30^{e}$ \\
\hline & $0.5 \%$ & $6.79 \pm 0.37^{\mathrm{e}}$ & $6.85 \pm 0.35^{\mathrm{e}}$ \\
\hline & $1.0 \%$ & $6.74 \pm 0.30^{\mathrm{e}}$ & $6.80 \pm 0.31^{e}$ \\
\hline & $2.0 \%$ & $6.37 \pm 0.33^{\mathrm{e}}$ & $6.15 \pm 0.28^{\mathrm{e}}$ \\
\hline \multirow{4}{*}{1} & $0 \%$ & $7.58 \pm 0.38^{d}$ & $7.62 \pm 0.40^{\mathrm{d}}$ \\
\hline & $0.5 \%$ & $7.75 \pm 0.34^{d}$ & $7.78 \pm 0.38^{d}$ \\
\hline & $1.0 \%$ & $7.53 \pm 0.36^{d}$ & $7.64 \pm 0.34^{d}$ \\
\hline & $2.0 \%$ & $7.41 \pm 0.30^{\mathrm{d}}$ & $7.55 \pm 0.38^{\mathrm{d}}$ \\
\hline \multirow{4}{*}{2} & $0 \%$ & $7.86 \pm 0.39^{d}$ & $7.93 \pm 0.37^{\text {cd }}$ \\
\hline & $0.5 \%$ & $8.33 \pm 0.42^{\mathrm{bc}}$ & $8.59 \pm 0.40^{b}$ \\
\hline & $1.0 \%$ & $8.19 \pm 0.37^{\mathrm{bc}}$ & $8.06 \pm 0.39^{\mathrm{c}}$ \\
\hline & $2.0 \%$ & $8.21 \pm 0.40^{\mathrm{bc}}$ & $8.42 \pm 0.44^{\text {bc }}$ \\
\hline \multirow{4}{*}{3} & $0 \%$ & $8.30 \pm 0.45^{\mathrm{bc}}$ & $8.41 \pm 0.44^{\mathrm{bc}}$ \\
\hline & $0.5 \%$ & $8.56 \pm 0.42^{\mathrm{b}}$ & $8.77 \pm 0.48^{b}$ \\
\hline & $1.0 \%$ & $8.71 \pm 0.49^{\mathrm{ab}}$ & $8.73 \pm 0.48^{b}$ \\
\hline & $2.0 \%$ & $8.66 \pm 0.46^{b}$ & $8.67 \pm 0.43^{\mathrm{b}}$ \\
\hline \multirow{4}{*}{4} & $0 \%$ & $8.15 \pm 0.42^{c}$ & $8.90 \pm 0.50^{\mathrm{ab}}$ \\
\hline & $0.5 \%$ & $8.96 \pm 0.51^{\mathrm{ab}}$ & $9.68 \pm 0.55^{\mathrm{a}}$ \\
\hline & $1.0 \%$ & $9.19 \pm 0.48^{\mathrm{a}}$ & $9.62 \pm 0.52^{\mathrm{a}}$ \\
\hline & $2.0 \%$ & $9.01 \pm 0.46^{\mathrm{a}}$ & $9.16 \pm 0.48^{\mathrm{ab}}$ \\
\hline \multirow{4}{*}{5} & $0 \%$ & $8.24 \pm 0.40^{\mathrm{bc}}$ & $8.54 \pm 0.45^{b}$ \\
\hline & $0.5 \%$ & $8.87 \pm 0.44^{\mathrm{ab}}$ & $9.11 \pm 0.52^{\mathrm{ab}}$ \\
\hline & $1.0 \%$ & $8.78 \pm 0.44^{\mathrm{ab}}$ & $8.96 \pm 0.40^{\mathrm{ab}}$ \\
\hline & $2.0 \%$ & $8.65 \pm 0.40^{b}$ & $8.77 \pm 0.48^{\mathrm{ab}}$ \\
\hline \multirow{4}{*}{6} & $0 \%$ & $8.52 \pm 0.42^{b}$ & $8.26 \pm 0.40^{c}$ \\
\hline & $0.5 \%$ & $8.49 \pm 0.48^{b}$ & $8.50 \pm 0.47^{b}$ \\
\hline & $1.0 \%$ & $8.60 \pm 0.46^{b}$ & $8.37 \pm 0.43^{\mathrm{bc}}$ \\
\hline & $2.0 \%$ & $8.44 \pm 0.42^{b}$ & $8.22 \pm 0.41^{\mathrm{c}}$ \\
\hline \multirow{4}{*}{7} & $0 \%$ & $8.36 \pm 0.42^{b}$ & $8.00 \pm 0.46^{c}$ \\
\hline & $0.5 \%$ & $8.23 \pm 0.40^{\mathrm{bc}}$ & $8.18 \pm 0.44^{c}$ \\
\hline & $1.0 \%$ & $8.13 \pm 0.40^{c}$ & $8.14 \pm 0.42^{\mathrm{c}}$ \\
\hline & $2.0 \%$ & $8.11 \pm 0.44^{\mathrm{c}}$ & $8.19 \pm 0.42^{c}$ \\
\hline
\end{tabular}

${ }^{1)}$ Sacch cerevisiae KCCM 12684 seeds were innoculated by $5.0 \%$ (v/v) into makgeolli and fermented at $25^{\circ} \mathrm{C}$ for 7 days.

${ }^{2)}$ All values are means \pm SD of determinations in three independent experiments. Means with different lowercase letters $(a, b, c, d$, and e) indicate significant $(p<0.05)$ differences of fermentation times by Tukey's multiple range test.
$(1,6,20)$.

\section{발효 중 수용성 phenolics 함량 변화}

BMP-RN을 이용하여 제조한 막걸리의 발효 동안 수용성 phenolics 함량 변화는 Fig. 1과 같았다. 수용성 phenolics 함량은 여주 분말 첨가량이 증가할수록 유의적으로 증가하 였고, 발효가 진행됨에 따라 역시 유의적으로 증가하였다. 담금 직후 무첨가 막걸리는 $0.92 \mathrm{mg} / \mathrm{mL}$ 에서 발효 7일째 $1.85 \mathrm{mg} / \mathrm{mL}$ 로 증가하였고, 첨가 막걸리는 발효 0 일째 1.01(0.5\% BMP-RN)-1.41(2.0\% BMPP-RN) mg/mL에서 발 효 7일째 각각 2.03(0.5\% BMP-RN), 2.24(1.0\% BMP-RN) 및 2.48(2.0\% BMP-RN) mg/mL로 담금 직후 보다 약 1.3 1.5 배 정도 증가하였다.

한편 플라보노이드 등의 폴리페놀 화합물은 식물체내 2 차 대사산물로서 항산화 및 항균 등 다양한 생리활성을 나타내며, 특히 항산화 활성은 phenolics 화합물이 관여하는 것으로 보고되고 있다 $(11,22)$. Cho 등(1)은 자색고구마 분말 첨가 누룩으로 제조한 막걸리 역시 발효 전보다 발효 후에 수용성 phenolics 함량이 증가한 것으로 보고하여 본 연구와 동일하였으며, 이 이유는 발효가 진행됨에 따라 누룩으로 부터 미생물의 효소작용에 의해 유리형 phenolics가 생성되 어 수용성 phenolics 함량이 증가한 것으로 추정하였다.

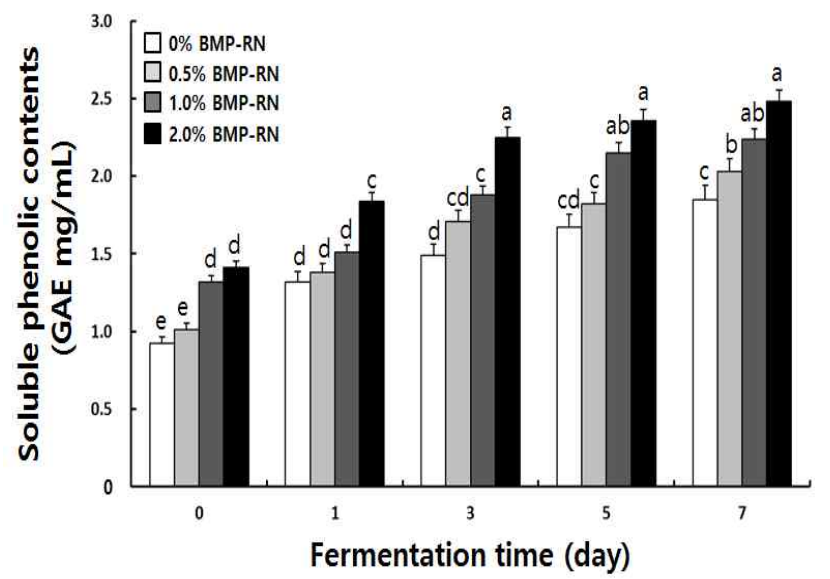

Fig. 1. Change in soluble phenolic contents (SPCs) of makgeolli during makgeolli fermentation using different bitter melon powder-rice nuruk (BMP-RN).

BMP-RN, Sacch. cerevisiae KCCM 12684 seeds were innoculated [5.0\% (v/v)] into makgeolli and fermented at $25^{\circ} \mathrm{C}$ for 7 days. All values are means $\pm \mathrm{SD}$ of determinations in three independent experiments. Means with different lowercase letters (a, b, c, d, and e) indicate significant $(\mathrm{p}<0.05)$ differences of fermentation times by Tukey's multiple range test.

\section{발효 중 항산화 활성 변화}

BMP-RN을 이용하여 제조한 막걸리의 발효 중 항산화 활성은 Fig. 2-4와 같았다. 항산화 활성은 수용성 phenolics 함량의 증가와 동일하게 발효가 진행됨에 따라 유의적으로 증가하였으며, 여주 분말 첨가 막걸리들(BMP-RNs)은 여주 분말 무첨가 막걸리(일반 막걸리)보다 DPPH 라디칼 소거 
활성은 약 1.2 1.5배 및 $\mathrm{ABTS}$ 라디칼 소거활성은 약 1.1 1.3배 및 환원력은 1.1 1.5배 높았다.

$\mathrm{DPPH}$ 라디칼 소거활성은 여주 분말 첨가량이 증가할수 록 유의적으로 증가하였고 발효가 진행됨에 따라 역시 증가 하였으며, 담금 직후 여주 분말이 첨가되지 않은 무첨가구 막걸리는 담금 직후 $46.95 \%$ 에서 발효 종기(7일째) $54.98 \%$ 발효 전보다 약 1.2 배 정도 증가하였다. 여주 분말 첨가 누룩으로 제조한 막걸리는 발효 0일째 $52.78 \%(0.5 \%$ $\mathrm{BMP}-\mathrm{RN})-70.04 \%(2.0 \% \mathrm{BMP}-\mathrm{RN})$ 에서 발효 7일째 각각 63.10\%(0.5\% BMP-RN), 71.75\%(1.0\% BMP-RN) 및 83.40\% (2.0\% BMP-RN)로 담금 직후 보다 약 1.2 배 정도 증가하였 다(Fig. 2).

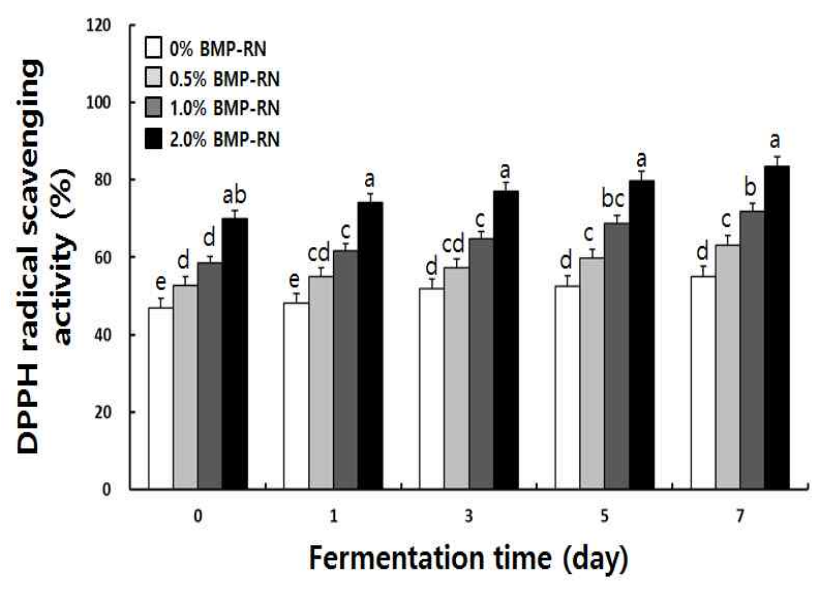

Fig. 2. Change in DPPH radical scavenging activity of makgeolli during fermentation using different bitter melon powder-rice nuruk (BMP-RN).

BMP-RN, Sacch. cerevisiae KCCM 12684 seeds were innoculated [5.0\% (v/v)] into makgeolli and fermented at $25^{\circ} \mathrm{C}$ for 7 days. All values are means $\pm \mathrm{SD}$ of determinations in three independent experiments. Means with different lowercase letters (a, b, c, d, and e) indicate significant $(\mathrm{p}<0.05)$ differences of fermentation times by Tukey's multiple range test.

$\mathrm{ABTS}$ 라디칼 소거활성 역시 여주 분말 첨가량이 증가할 수록 활성이 유의적으로 증가하였으며, 발효가 진행됨에 따라 활성이 증가하였다. $0 \% \mathrm{BMP}-\mathrm{RN}$ (여주 분말 무첨가 구)은 발효 초기보다 약 1.3 배, $0.5 \%$ BMP-RN은 1.4 배, $1.0 \%$ $\mathrm{BMP}-\mathrm{RN}$ 은 1.3배 및 2.0\% BMP-RN은 1.2배 증가하였다 (Fig. 3).

BMP-RN을 이용하여 제조한 막걸리의 발효 중 환원력을 살펴본 결과는 Fig. 4와 같았다. 환원력 역시 DPPH 및 $\mathrm{ABTS}$ 라디칼 소거활성들과 동일하게 자색고구마 첨가량 이 증가할수록 활성이 유의적으로 증가하였으며, 발효가 진행됨에 따라 역시 증가하였다. 담금 직후 여주 무첨가 누룩으로 제조한 막걸리는 0.629 에서 발효 7일째 0.964 로 증가하였고, 여주 분말 첨가 누룩으로 제조한 막걸리는 발 효 0일째 0.709(0.5\% BMP-RN)-1.243(2.0\% BMP-RN)에서 발효 7일째 각각 1.075(0.5\% BMP-RN), 1.279(1.0\% BMP-RN)
및 1.455(2.0\% BMP-RN)로 증가하였다.

일반적으로 phenolics 함량과 항산화 활성 간에 상관관계 가 있는 것으로 널리 알려져 있는데, 이들은 인체 내에서 지질, 단백질과 결합하여 각종 질병 및 노화를 일으키는 산화성 free radical의 반응을 정지시키는 것으로 알려져 있다 $(1,11,14,15)$. 본 연구에서도 여주 분말 무첨가구( $0 \%$ $\mathrm{BMP}-\mathrm{RN}$ )보다 여주 분말 첨가구에서 $\mathrm{DPPH}$ 라디칼 소거활 성이 높은 이유는 여주 분말의 수용성 phenolics에 기인한 것으로 추정되었고, 자색고구마 분말 첨가 누룩으로 제조 한 막걸리(1)와 함초 첨가 누룩으로 제조한 막걸리(10)에서 도 본 연구와 동일한 결과를 보고하였다.

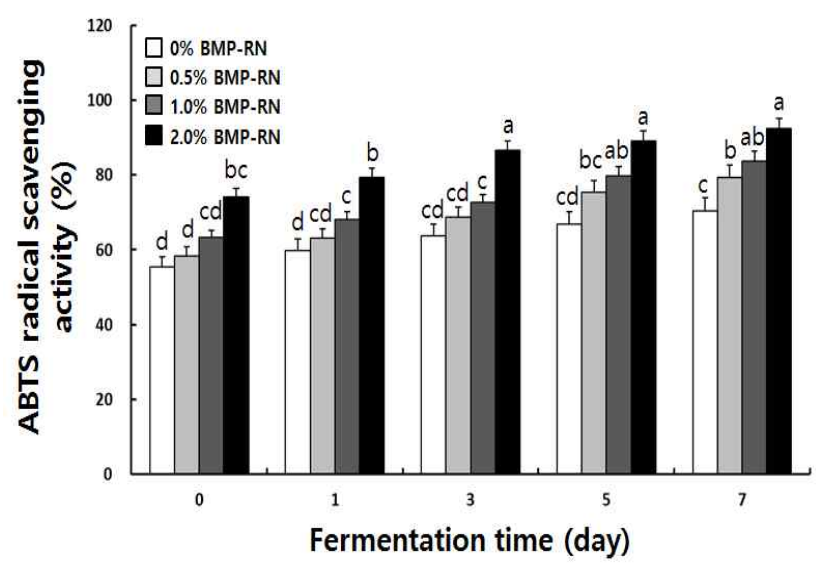

Fig. 3. Change in ABTS radical scavenging activity during makgeolli fermentation using different bitter melon powder-rice nuruk (BMP-RN).

BMP-RN, Sacch. cerevisiae KCCM 12684 seeds was innoculated [5.0\% (v/v)] into makgeolli and fermented at $25^{\circ} \mathrm{C}$ for 7 days. All values are means $\pm \mathrm{SD}$ of determinations in three independent experiments. Means with different lowercase letters $(\mathrm{a}, \mathrm{b}, \mathrm{c}$, and d) indicate significant $(\mathrm{p}<0.05)$ differences of fermentation times by Tukey's multiple range test.

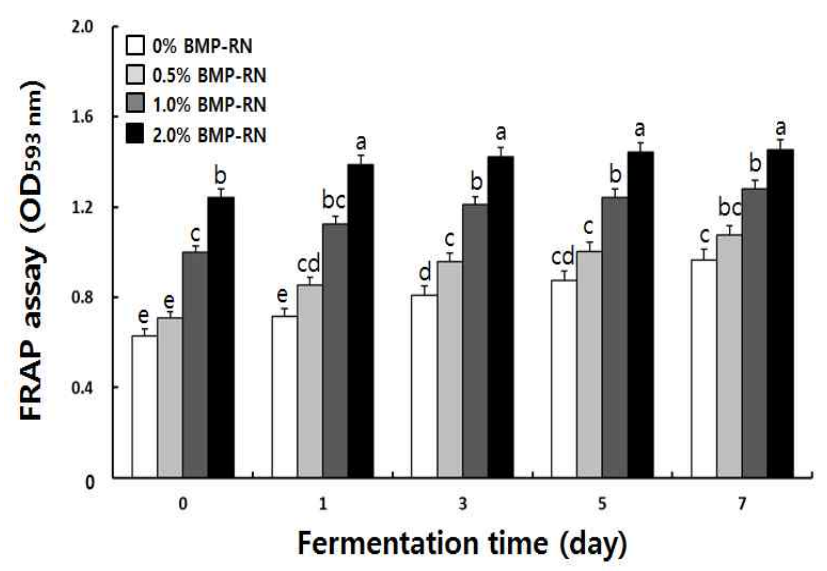

Fig. 4. Change in FRAP value of makgeolli during fermentation using different bitter melon powder-rice nuruk (BMP-RN).

BMP-RN, Sacch. cerevisiae KCCM 12684 seeds were innoculated $[5.0 \%$ (v/v)] into makgeolli and fermented at $25^{\circ} \mathrm{C}$ for 7 days. All values are means $\pm \mathrm{SD}$ of determinations in three independent experiments. Means with different lowercase letters $(a, b, c, d$ and e) indicate significant $(\mathrm{p}<0.05)$ differences of fermentation times by Tukey's multiple range test. 
본 연구에서는 쌀누룩 제조 시 여주 분말을 첨가하여 여주 분말-쌀누룩(BMP-RN)을 제조하였다. BMP-RN을 이 용하여 막걸리를 담금하고 발효 중 품질 특성과 항산화 활성을 살펴보았다. 막걸리 발효 중 $\mathrm{pH}$ 는 감소하였고 총산, 당도 및 알코올 함량은 증가하였다. 한편 발효 중 수용성 phenolics 함량이 증가함에 따라 DPPH와 ABTS 라디칼 소 거활성 및 환원력의 항산화 활성이 증가하였다. 앞으로 좀 더 많은 생리활성 검정실험이 수행되어져야 할 것으로 사료 되며, 본 연구에 의해 개발된 여주 분말-쌀누룩을 이용하여 새로운 형태의 기능성 막걸리 개발을 위한 기초 자료로 활용할 수 있을 것이다.

\section{요 약}

본 연구에서는 기능성이 밝혀져 있는 여주 분말을 첨가 하여 쌀누룩을 제조하고 이 누룩을 이용하여 막걸리를 제조 하였다. 여주 분말-쌀누룩(BMP-RN)은 BMP를 $0,0.5,1.0$ 및 $2.0 \%$ 로 쌀에 첨가하여 제조하였고, 막걸리 발효가 진행 되는 동안 발효 특성, 미생물 특성 및 항산화 특성을 확인하 였다. 막걸리 발효 중 $\mathrm{pH}$ 는 담금 직후(발효 0 일째) 각각 4.52(0\% BMP-RN), 4.93(0.5\%), 4.80(1.0\%) 및 4.88(2.0\%)에 서 발효 7일째 4.15, 4.30, 4.57 및 4.77로 감소하였고, 이에 상응하여 총산은 $0.60 ~ 0.78 \%$ 에서 $1.18-1.42 \%$ 로 증가하였 다. 가용성 고형분은 발효 초기(0일째) $2.2 \sim 4.4{ }^{\circ} \mathrm{Brix}$ 에서 발효 종기(7일째)8.6 9.3 ${ }^{\circ} \mathrm{Brix}$ 로 증가하였고 알코올 함량 은 발효 종기 $13.0 \%$ 로 증가하였다. 한편, 수용성 phenolics 함량은 발효 0 일째 각각 $0.92 ~ 1.41 \mathrm{mg} / \mathrm{mL}$ 에서 발효 종기(7 일째) $1.85 ~ 2.48 \mathrm{mg} / \mathrm{mL}$ 로 증가하였고 이에 상응하여 $\mathrm{DPPH}$ 와 $\mathrm{ABTS}$ 라디칼 소거활성 및 $\mathrm{FRAP}$ 환원력은 각각 발효 0일째 46.95 70.04\%, 55.33 74.13\% 및 0.629 1.243에서 발 효 7일째 54.98 83.4\%, 70.34 92.39\% 및 0.964 1.455로 증 가하였다. 여주 분말 첨가 막걸리가 여주 분말 무첨가 막걸 리(일반 막걸리)보다 수용성 phenolics 및 항산화 활성이 높았다. 이 결과로 여주-쌀누룩을 이용하여 기능성 막걸리 제조가 가능할 수 있을 것으로 판단되었다.

\section{감사의 글}

이 논문은 2014년 국립경남과학기술대학교의 기성회 연 구비에 의하여 연구되었습니다.

\section{References}

1. Cho HK, Lee JY, Seo WT, Kim MK, Cho KM (2012)
Quality characteristics and antioxidant effects during makgeolli fermentation by purple sweet potato-rice nuruk Korean J Food Sci Technol, 44, 728-735

2. Jeon MJ, Jang MK, Lee SJ, Park SH, Kim MH, Shon JH, Lee HS, Lee DG, Lee SH (2013) Variations of properties and microbial community during fermentation of makgeollies by isolated yeasts from traditional makgeollies. J Life Sci, 23, 796-803

3. Cho CW, Rhee YK, Lee YC, Kim YC, Shin KS, Nam SH, Hong HD (2014) Immunomodulatory activity of crude polysaccharides from makgeolli. J Korean Soc Food Sci Nutr 43, 238-242

4. Song YR, Lim BU, Song GS, Baik SH (2015) Quality characteristics and antioxidant activity of makgeolli supplemented with omija berries (Schizandra chinensis Baillon). Korean J Food Sci Technol, 47, 328-335

5. Wang SJ, Lee HJ, Cho JY, Park KH, Moon JH (2012) Isolation and identification of antioxidants from makgeolli. Korean J Food Sci Technol, 44, 14-20

6. Lee JW, Shim JY (2010) Quality characteristics of makgeolli during freezing storage. Food Eng Prog, 14, 328-334

7. Seo WT, Cho HK, Lee JY, Kim B, Cho KM (2012) Quality characteristics of wheat-rice makgeolli by making of rice nuruk prepared by Rhizopus oryzae CCS01. Korean J Microbiol, 48, 147-155

8. So MH, Lee YS (2009) Effects of culture conditions of Rhizopus sp. ZB9 on the production of saccharifying amylase during the preparation of rice koji. Korean $\mathrm{J}$ Food Nutr, 22, 644-649

9. Woo SM, Shin JS, Seong JH, Yeo SH, Choi JH, Kim TY, Jeong YJ (2010) Quality characteristics of brown rice takju by different nuruks. J Korean Soc Food Sci Nutr, 39, 301-307

10. Jeon BY, Seo HN, Yun AR, Lee IH, Park DH (2010) Effect of glasswort (Salicornia herbacea L.) on nuruk-making process and makgeolli quality. Food Sci Biotechnol, 19, 999-1004

11. Choi JS, Kim HY, Seo WT, Lee JH, Cho KM (2012) Roasting enhances antioxidant effect of bitter melon (Momodica charnatia L.) increasing in flavan-3-ol and phenolic acid contents. Food Sci Biotechnol, 21, 19-26

12. Lee HY, Park KS, Joo OS, Hwang CE, Ahn MJ, Jeong YS, Hong SY, Kwon OK, Kang SS, Yuk HJ, Kim HR, Park DS, Cho KM (2015) Changes in quality characteristics and antioxidant activity of bitter melon (Momordica charantia L.) pickle during ageing. J Korean 
Soc Food Sci Nutr, 44, 401-411

13. Ng ZX, Chua KH, Kuppusamy UR (2014) Proteomic analysis of heat treated bitter gourd (Momordica charantia L. var. Hong Kong Green) using 2D-DIGE. Food Chem, 148, 155-161

14. Cho KM, Joo OS (2015) Change in phytoestrogen contents and antioxidant activity during fermentation of cheonggukjang with bitter melon. Korean J Food Preserv, 22, 119-128

15. Cho KM, Joo OS (2014) Quality and antioxidant characteristics of Elaeagnus multiflora wine through the thermal processing of juice. Korean J Food Preserv, 21, 206-214

16. Folin O, Denis W (1912) On phosphotungstic-phosphomolybdic compounds as color reagents. J Biol Chem, 12, 239-243

17. Kim JY, Yi YH (2010) pH, acidity, color, amino acids, reducing sugars, total sugars, and alcohol in puffed millet powder containing millet takju during fermentation. Korean J Food Sci Technol, 42, 727-732

18. Choi JH, Jeon JA, Jung ST, Park JH, Park SY, Lee CH,
Kim TJ, Choi HS, Yeo SH (2011) Quality characteristics of seoktanju fermented by using different nuruks. Korean J Microbiol Biotechnol, 39, 56-62

19. Kim SY, Kim EK, Yoon SJ, Jo NJ, Jung SK, Kwon SH, Chang YH, Jeong YH (2011) Physicochemical and microbial properties of Korean traditional rice wine, makgeolli supplemented with cucumber during fermentation. J Korean Soc Food Sci Nutr, 40, 223-228

20. Kim GM, Jung WJ, Shin JH, Kang MJ, Sung NJ (2011) Preparation and quality characteristics of makgeolli made with black garlic extract and sulgidduk. J Korean Soc Food Sci Nutr, 40, 759-766

21. Jin TY, Chung HJ, Eun JB (2006) The effect of fermentation temperature on the quality of jinyangju, a Korean traditional rice wine. Korean J Food Sci Technol, 38, 414-418

22. Joo OS, Kang ST, Jeong CH, Lim JW, Park YG, Cho KM (2011) Manufacturing of the enhances antioxidative wine using a ripe daebong persimmon (Dispyros kaki L). J Appl Biol Chem, 54, 126-134 